\title{
Prognostic value of the electrocardiogram in endocardial fibroelastosis
}

\author{
Delores A. Danilowicz ${ }^{1}$ \\ From Fohns Hopkins Hospital, Baltimore, Maryland, U.S.A.
}

Nine children with endocardial fibroelastosis were followed from the time of admission with congestive heart failure until either death or discharge. Review of multiple clinical features showed that only the electrocardiographic pattern could be correlated with death or survival. The presence of a delayed transition zone with anterior force loss on the initial electrocardiogram ('infarct pattern') was noted in all the children who died. Progression of these changes with a pattern of anterolateral 'infarct' in two and inferior wall 'infarct' in two occurred before death. Necropsy on three of the four children confirmed the diagnosis of endocardial fibroelastosis. There was extensive fibrosis and thinning of the left ventricular myocardium as well as involvement of the mitral valve structures. Review of published cases supports the view that an 'infarct' pattern in a child with endocardial fibroelastosis is usually associated with death and that this pattern is a negative prognostic sign for survival.

Primary endocardial fibroelastosis (EFE) usually occurs in infants under 1 year of age and presents with congestive heart failure (Manning and Keith, 1964; Forfar et al., 1964). There is thickening of the endothelial layer of the left ventricle, often with extension on to the papillary muscles, chordae, and mitral valve leaflets. The left atrium may also be involved while the right side is less frequently affected. Mitral regurgitant murmurs, resulting either from dilatation of the left ventricle or from involvement of mitral valve structures, are common (Moller et al., 1964). Secondary EFE is often associated with congenital heart lesions, especially left heart obstruction or underdevelopment (McCormick, 1958; Sellers, Keith, and Manning, 1964). It may also be seen in acquired heart disease but is usually patchy in its distribution.

EFE occurs in dilated and constricted forms (Moller et al., 1964; Lambert and Vlad, 1958). The former is the more common primary type seen in infants; the latter is seen more frequently in adults where the left ventricular chamber is normal in size but the ventricular wall is greatly thickened (Van Buchem, Arends, and Schröder, 1959). Whether EFE in these two forms is a single entity remains

Received 21 July 1975.

1Present address: New York University Medical Center, 550 First Avenue, New York, New York 10016, U.S.A. uncertain; EFE is now frequently regarded as a form of endomyocardial fibrosis, which may have a number of aetiologies (Apley, 1961; Hastreiter and Miller, 1964).

EFE in children has usually been a diagnosis of exclusion; only occasional biopsies have been done during life, and commonly the diagnosis is only confirmed at necropsy (Manning and Keith, 1964; Forfar et al., 1964; Moller et al., 1964; Hastreiter and Miller, 1964). However, a significant percentage of children with this diagnosis do recover and apparently return to normal cardiac function. In nine children with EFE, seen at the Johns Hopkins Hospital, the presenting electrocardiogram and its subsequent changes seemed to correlate best with the eventual outcome. A full evaluation was undertaken in these nine children, with follow-up until death in four, discharge from clinic in four, and loss to follow-up in one.

\section{Clinical material}

Nine children, eight Negro and one Caucasian, three male and six female, were followed from 1964 to 1972 , when the children were either dead or discharged from follow-up.

The nine patients were initially admitted to the hospital when they were aged 3 to 10 months, with 
TABLE 1 Clinical features on admission

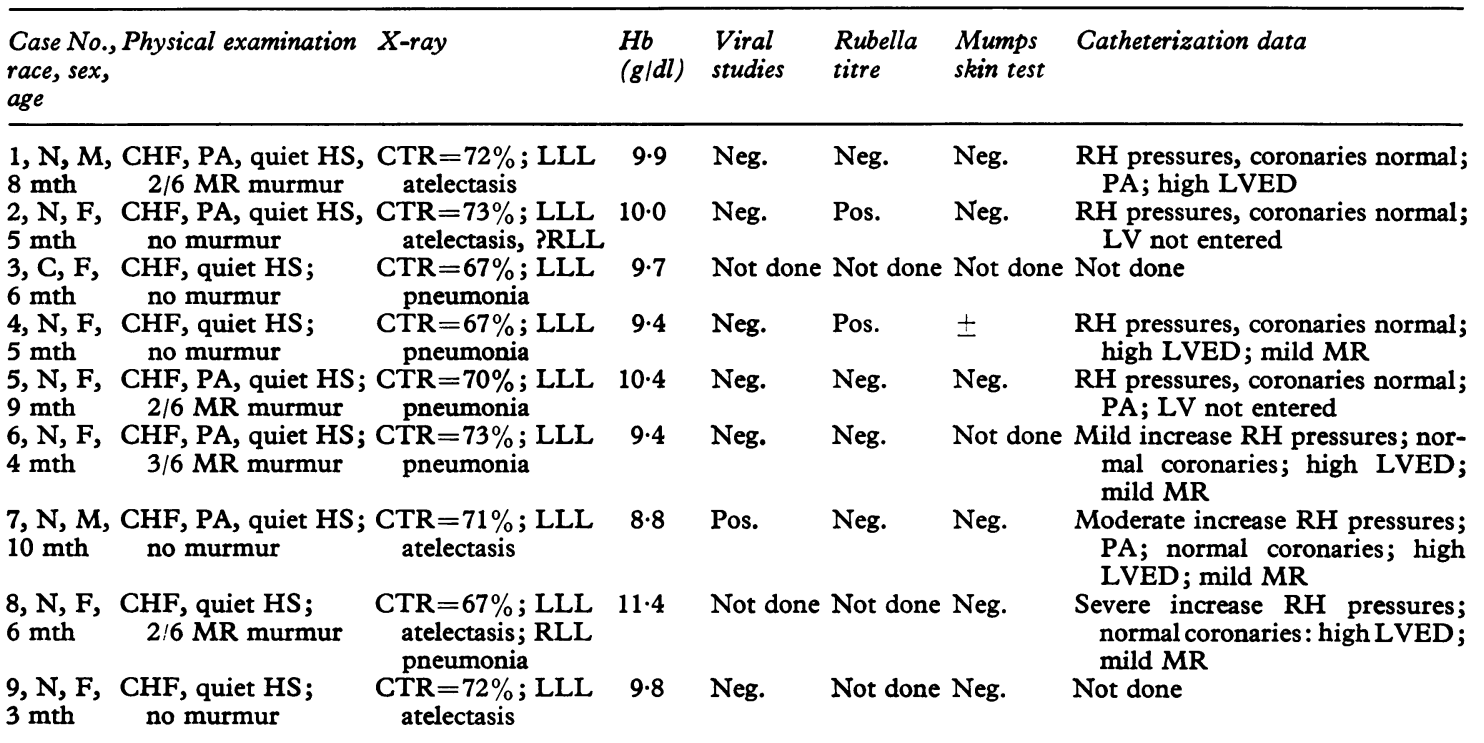

N, Negro; C, Caucasian; CHF, congestive heart failure; CTR, cardiothoracic ratio; HS, heart sounds; LLL, left lower lobe; LVED, left ventricular end-diastolic pressure; $m$ th, months; $M R$, mitral regurgitation; PA, pulsus alternans; RLL, right lower lobe; RH, right heart; \pm , equivocal.

the diagnosis of congestive heart failure and either left lower lobe atelectasis (5) or left lower lobe pneumonia (4); two also had right lower lobe opacities (Table 1). On physical examination, all were in congestive failure with quiet heart sounds; four had pulsus alternans and four had murmurs of mitral regurgitation. All were anaemic $(\mathrm{Hb} 8.8-$ $11.4 \mathrm{~g} / \mathrm{dl}$ ). All had increased cardiothoracic ratios $(67-73 \%)$, as a result of left ventricular and left atrial enlargement, and pulmonary venous engorgement. Viral studies ${ }^{1}$ were negative in six, and a rise in Coxsackie titres were observed in one. Rubella antibody titres were done in six and were positive in two. Mumps skin test was done in seven, with negative results in six and an equivocal response in one. Cardiac catheterization in seven children showed normal coronary arteries in all, and no associated congenital defect. Four had normal right heart pressures, while in the remaining three these pressures were raised in varying degree. Pulsus alternans was present in four. The left ventricle was entered in five of the seven and the end-diastolic pressure was high in all. Of the four who had left ventricular cineangiography, all showed mila mitral regurgitation, with a dilated and poorly contracting left ventricle.

${ }^{1}$ Acute and convalescent sera for antibody titres for Coxsackie $A$ and B, Echo, and in some cases other viruses, and nasopharyngeal and stool cultures for viral isolation.
Preadmission history is shown in Table 2. Eight children were born at full term, with normal birthweights, and one was delivered prematurely with a birthweight of $1558 \mathrm{~g}$. Sibling rank varied from first to eighth, with maternal age from 17 to 30 years. Four mothers had had mumps in childhood, two had not, and three were uncertain. Prenatal complications were absent in four; premature rupture of membranes, with premature delivery occurred in one mother; mild toxaemia was present in four, and exposure to rubella in the first trimester occurred in one. Family history was negative in four. Two mothers had had previous early miscarriages and one of these had had two previous premature infants as well. Three mothers had asthma but were not on continuous therapy at the time of pregnancy. One mother had sickle trait and epilepsy, for which she was treated with phenytoin. Family history of heart disease was limited to rheumatic heart disease in one father and unknown heart disease causing death at age 16 in another paternal aunt.

After discharge, all children were followed in the outpatient department (Table 3). All responded initially to treatment with digoxin and 3 subsequently continued to do well with a decrease in heart size on $x$-ray and no recurrence of heart failure or respiratory infections. One of these three was restudied at age 4 years with normal catheterization results. All three were taken off digoxin at 
TABLE 2 Pre-admission history

\begin{tabular}{|c|c|c|c|c|c|c|}
\hline Case No. & Birth weight $(g)$ & Maternal age (y) & $\begin{array}{l}\text { Sibling } \\
\text { rank }\end{array}$ & $\begin{array}{l}\text { History of mumps } \\
\text { in mother }\end{array}$ & Prenatal complications & Family history \\
\hline 1 & 3345 & 21 & 1 & Unknown & Mild toxaemia & Negative \\
\hline 2 & 2380 & 17 & 1 & Yes & None & $\begin{array}{l}\text { Sickle trait and epilepsy } \\
\text { in mother; RHD in } \\
\text { father }\end{array}$ \\
\hline 3 & 3684 & 24 & 3 & Yes & $\begin{array}{l}\text { Rubella exposure in } \\
\text { 1st trimester; } \\
\text { mild toxaemia }\end{array}$ & $\begin{array}{l}\text { Asthma in mother; one } \\
\text { previous miscarriage }\end{array}$ \\
\hline 4 & 2749 & 17 & 2 & No & None & Asthma in mother \\
\hline 5 & 2976 & 26 & 2 & Yes & None & Negative \\
\hline 6 & 3032 & 21 & 2 & No & Mild toxaemia & Asthma in mother \\
\hline 7 & 4167 & 30 & 8 & Unknown & $\begin{array}{l}\text { Excess weight gain: } \\
\text { on iron and 'diet } \\
\text { pills' }\end{array}$ & Negative \\
\hline 8 & 1558 & 25 & 4 & Unknown & $\begin{array}{l}\text { Premature rupture of } \\
\text { membranes }\end{array}$ & $\begin{array}{l}3 \text { of } 4 \text { children prema- } \\
\text { ture; one miscar- } \\
\text { riage; paternal aunt } \\
\text { died at age } 16 \text { from } \\
\text { unknown heart dis- } \\
\text { ease }\end{array}$ \\
\hline 9 & 2268 & 26 & 3 & Yes & None & Negative \\
\hline
\end{tabular}

RHD, rheumatic heart disease.

TABLE 3 Course of illness

\begin{tabular}{|c|c|c|c|c|c|}
\hline Case No. & Clinical course & $X$-ray & $\begin{array}{l}\text { Age at } \\
\text { death }\end{array}$ & Discharge & Repeat catheterization \\
\hline 1 & $\begin{array}{l}\text { Continued CHF with } \\
\text { recurrent infections; } \\
\text { MR, increasing }\end{array}$ & $\begin{array}{l}\text { CTR from } 72 \text { to } 82 \% \text {; } \\
\text { recurrent LLL } \\
\text { atelectasis }\end{array}$ & 17 mth & 一 & No \\
\hline 2 & $\begin{array}{l}\text { Recurrent infections } \\
\text { with FTT for one } \\
\text { year; then improved; } \\
\text { no murmur }\end{array}$ & $\begin{array}{l}\text { Lungs clear: CTR from } \\
73 \text { to } 55 \%\end{array}$ & 一 & $\begin{array}{l}\text { Off digoxin at } 3 \text { years; } \\
\text { discharged at } 5 \text { years }\end{array}$ & $\begin{array}{l}\text { Yes: normal study at } 4 \\
\text { years }\end{array}$ \\
\hline 3 & $\begin{array}{l}\text { No further problems; } \\
\text { no murmur }\end{array}$ & $\begin{array}{l}\text { Lungs clear; CTR from } \\
67 \text { to } 51 \%\end{array}$ & 一 & $\begin{array}{c}\text { Off digoxin at } 3 \frac{1}{\mathrm{z}} \text { years; } \\
\text { discharged at } 5 \text { years }\end{array}$ & No \\
\hline 4 & $\begin{array}{l}\text { Recurrent infections, } \\
\text { persistent anaemia; } \\
\text { FTT; borderline } \\
\text { CHF; no murmur }\end{array}$ & $\begin{array}{l}\text { Lungs clear; CTR } \\
\text { same at } 67 \%\end{array}$ & 16 mth & - & No \\
\hline 5 & $\begin{array}{l}\text { No further problems; } \\
\text { no murmur }\end{array}$ & $\begin{array}{l}\text { Lungs clear; CTR from } \\
70 \text { to } 60 \%\end{array}$ & 一 & $\begin{array}{l}\text { Off digoxin at } 3 \text { years; } \\
\text { left clinic }\end{array}$ & No \\
\hline 6 & $\begin{array}{l}\text { No further problems; } \\
\text { no murmur }\end{array}$ & $\begin{array}{l}\text { Lungs clear; CTR from } \\
73 \text { to } 58 \%\end{array}$ & - & $\begin{array}{r}\text { Off digoxin at } 3 \text { years; } \\
\text { discharged at } 5 \text { years }\end{array}$ & $\begin{array}{l}\text { Yes: normal study at } \\
4 \text { years }\end{array}$ \\
\hline 7 & $\begin{array}{l}\text { Continued CHF, re- } \\
\text { current infections; } \\
\text { MR murmur }\end{array}$ & $\begin{array}{l}\text { Persistent LLL } \\
\text { atelectasis; CTR } \\
\text { same at } 71 \%\end{array}$ & 30 mth & 一 & $\begin{array}{l}\text { Yes: } 18 \text { mth-impaired } \\
\text { LV function with high } \\
\text { LVED; MR (phenol- } \\
\text { ization at } 2 \text { years) }\end{array}$ \\
\hline 8 & $\begin{array}{l}\text { Continued CHF, re- } \\
\text { current infections; } \\
\text { intermittent MR }\end{array}$ & $\begin{array}{l}\text { Persistent LLL } \\
\text { atelectasis; CTR from } \\
67 \text { to } 70 \%\end{array}$ & 36 mth & 一 & No \\
\hline 1) & $\begin{array}{l}\text { Recurrent infections } \\
\text { with CHF for } 1 \text { year; } \\
\text { then improved; no } \\
\text { murmur }\end{array}$ & $\begin{array}{l}\text { Lungs clear; CTR from } \\
72 \text { to } 60 \%\end{array}$ & 一 & $\begin{array}{l}\text { Off digoxin at } 5 \text { years; } \\
\text { discharged at } 8 \text { years }\end{array}$ & $\begin{array}{l}\text { Yes: normal study at } \\
5 \text { years }\end{array}$ \\
\hline
\end{tabular}

CHF, congestive heart failure; CTR, cardiothoracic ratio; FTT, failure to thrive; LLL, left lower lobe; LV, left ventricle; LVED, left ventricular end-diastolic pressure; $M R$, mitral regurgitation. 
3 years of age. Two were discharged from clinic attendance at 5 years of age; the third was lost to follow-up at 3 years of age, clinically doing well. Six children, after initial improvement, continued to have recurrent infections with 'failure to thrive' and chronic congestive failure. Four of these died between the ages of 16 and 36 months. The other two children did poorly for about seven to twelve months but then improved. Digoxin was stopped at ages 3 and 5 years. Catheterization was performed at ages 4 and 5 years with normal results, except for possible slight impairment of left ventricular function in one. These two children continued to do well and were discharged from clinic at 5 and 8 years of age.

The four children who died all continued to have recurrent episodes of atelectasis, pneumonia, and heart failure. The anaemia persisted or worsened in spite of treatment; the cardiothoracic ratio initially showed no improvement and then increased. Two children developed a chronic left lower lobe atelectasis, and one of these collapsed the entire left lung during his terminal admission; these two died while in hospital and necropsy confirmed the diagnosis of EFE. The other two children died at home at 17 and 32 months of age. There was no necropsy on the former. The latter had had a phenolization done at 2 years of age, with minimal clinical change; necropsy on this infant also confirmed the diagnosis of EFE.

Various clinical features were examined for their prognostic value. All children were treated the same way with digoxin and diuretics initially. The digoxin was increased with growth until the age of 2 to 4 years in the five children who survived. The past history and the admission history were not remarkably different. Physical examination was not useful since all were in failure; pulsus alternans and mitral regurgitation were present in those survived and in those who died. Left lower lobe atelectasis with or without penumonia was present in all and cleared in all initially. All responded to treatment and were discharged; three maintained their improvement; two had continuing problems for seven and twelve months before manifesting further improvement; four continued with problems with no major periods of improvement up to the time of their deaths. The decrease in cardiothoracic ratio was slow, with even the 'normals' staying above 60 per cent for months and years. At 5 years of age, two children had a ratio of 51 and 58 per cent;

TABLE 4 Electrocardiographic features

\begin{tabular}{|c|c|c|c|}
\hline Case No. & Electrocardiogram on admission & Change in electrocardiogram & Result \\
\hline 1 & $\begin{array}{l}\text { LVH; axis }+120^{\circ} \text {; transition at V5; } \\
\text { ST elevation in anterior leads; T } \\
\text { waves inverted over left } \\
\text { praecordium }\end{array}$ & $\begin{array}{l}\text { Massive 'infarct' pattern with QS } \\
\text { in V1-6; ST elevation in anterior } \\
\text { leads }\end{array}$ & $\begin{array}{l}\text { Died: PM showed marked fibrosis of } \\
\text { LV with multiple thrombi; } \\
\text { confirmed EFE }\end{array}$ \\
\hline 2 & $\begin{array}{l}\text { LVH; axis }+20^{\circ} \text {; transition at V2; } \\
\text { ST elevation V1-3; depressed } \\
\text { V4-6; T wave inverted in left } \\
\text { leads }\end{array}$ & $\begin{array}{l}\text { Decrease in voltage; transition never } \\
\text { delayed; } \mathrm{ST} \text { return to normal; } \mathrm{T} \\
\text { wave normalization but some } \\
\text { flattening }\end{array}$ & $\begin{array}{l}\text { Alive and well; normal study at } 4 \\
\text { years of age; no medications }\end{array}$ \\
\hline 3 & $\begin{array}{l}\mathrm{LVH} \text {; axis }+50^{\circ} \text {; transition at } \mathrm{V} 3 \text {; } \\
\text { no ST changes; T wave inverted } \\
\text { in left leads }\end{array}$ & $\begin{array}{l}\text { Decrease in LV voltage; normal } \\
\text { ECG with upright T waves }\end{array}$ & Alive and well; no medications \\
\hline 4 & $\begin{array}{l}\text { LVH; axis }+60^{\circ} \text {; transition at V5; } \\
\text { ST elevation V1-3; T wave in- } \\
\text { verted in left leads }\end{array}$ & $\begin{array}{l}\text { Persistent } \mathrm{LVH} \text { and } \mathrm{T} \text { inversion; } \\
\text { transition always delayed }\end{array}$ & Died; no PM \\
\hline 5 & $\begin{array}{l}\text { LVH; axis }+40^{\circ} \text {; transition at } \mathrm{V} 2 \text {; } \\
\text { no ST changes; } T \text { wave inverted } \\
\text { in left leads }\end{array}$ & $\begin{array}{l}\text { Still had LVH at time lost to } \\
\text { follow-up; improved T waves }\end{array}$ & $\begin{array}{l}\text { Lost to follow-up; off digoxin and } \\
\text { clinically well }\end{array}$ \\
\hline 6 & $\begin{array}{l}\text { LVH; axis }+60^{\circ} \text {; transition at } \mathrm{V} 2 \text {; } \\
\text { ST elevation V1-3; T wave } \\
\text { inverted in left leads }\end{array}$ & Complete normalization & $\begin{array}{l}\text { Alive and well; normal study at } 4 \\
\text { years of age; no medications }\end{array}$ \\
\hline 7 & $\begin{array}{l}\text { LVH; axis }+20^{\circ} \text {; transition at } \mathrm{V} 6 \text {; } \\
\text { no ST changes; } T \text { wave inverted } \\
\text { in left leads }\end{array}$ & $\begin{array}{l}\text { Progressive loss of left, anterior, } \\
\text { inferior forces; LAD }-65^{\circ} ; \mathrm{T} \\
\text { wave changes }\end{array}$ & $\begin{array}{l}\text { Died } 4 \text { months after phenolization, } \\
\text { age } 30 \text { months; necropsy showed } \\
\text { EFE, fibrosis }++\end{array}$ \\
\hline 8 & $\begin{array}{l}\text { LVH; axis }+40^{\circ} \text {; transition at } \mathrm{V} 4 \text {; } \\
\text { no ST changes; T wave inverted } \\
\text { in left leads }\end{array}$ & $\begin{array}{l}\text { Loss of inferior forces with LAD } \\
-30^{\circ} \text {; increasing ST, T wave } \\
\text { changes; transition to V5-6 }\end{array}$ & $\begin{array}{c}\text { Died at } 3 \text { years; PM showed EFE } \\
\text { with fibrosis and thinning }++\end{array}$ \\
\hline 9 & $\begin{array}{l}\text { LVH; axis }+20^{\circ} \text {; transition at } \mathrm{V} 3 \text {; } \\
\text { no ST changes; } T \text { wave inverted } \\
\text { in left leads }\end{array}$ & $\begin{array}{l}\text { Borderline LVH; transition at V2 } \\
\text { with normal S-T, T waves }\end{array}$ & $\begin{array}{l}\text { Alive and well; normal study at } 5 \\
\text { years of age; on no medications }\end{array}$ \\
\hline
\end{tabular}




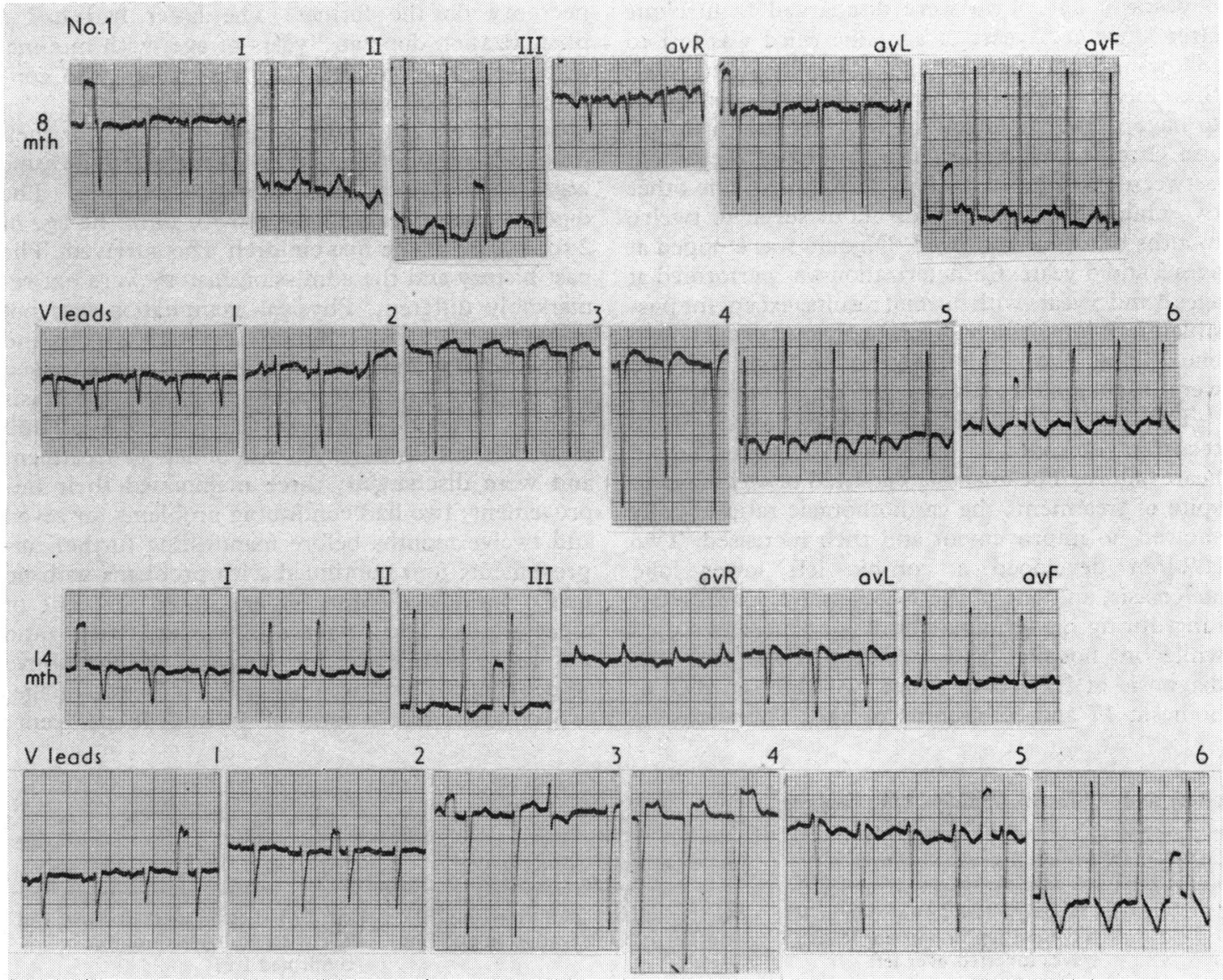

FIG. 1 The admitting electrocardiogram at 8 months of age and an electrocardiogram at 14 months, 2 months before death, for Case 1. Note the delayed transition in both, V4-5 at 8 months and V5-6 at 14 months. ST segment elevations are present in the mid-praecordial leads and $T$ wave inversion has increased in V6. Loss of anterior force was confirmed on vectorcardiogram with early posterior displacement of the outgoing limb on the transverse plane.

at 8 years of age, one child had a ratio of 60 per cent. After treatment of heart failure, cardiac catheterization was performed but showed no differences between the children who subsequently did well and those who died.

\section{Evaluation of electrocardiograms}

The admission electrocardiogram (Table 4) in all nine children showed left ventricular hypertrophy, with inversion of the $T$ waves in the left praecordial leads. ST segment changes were variable or absent. Mean QRS axis ranged from $+20^{\circ}$ to $+120^{\circ}$. Three children had obvious loss of anterior force with a delayed transition zone (two in V5, one in V6); this was confirmed by vectorcardiography in two, with early posterior displacement of the outgoing limb in the transverse plane with a resultant clockwise loop. Two children had suggestive loss of anterior force, with a transition in V4 in one and V2 in the other. Vectorcardiograms on these showed an early posterior displacement only in the first.

In the five children who survived, the electrocardiogram never showed a loss of myocardial forces initially or during the subsequent hospital course and follow-up in the outpatient clinic. Though regression of the left ventricular hypertrophy pattern 
was often slow, there was improvement in the ST segments and $T$ waves somewhat earlier. In the four children who died, anterior force loss was obvious in three and suggestive in one initially. The delayed transitional zone persisted or extended in all four. In two, the pattern resembled that of an anterolateral infarct (Fig. 1). In the other two, the more impressive loss of force was inferoposterior. Both of these children developed a left axis deviation $\left(-65^{\circ}\right.$ and $\left.-30^{\circ}\right)$ during the follow-up period (Fig. 2). One of the two children with the anterolateral 'infarct' pattern showed massive fibrosis of the apex and lateral wall of the left ventricle at necropsy. Multiple areas of thrombus formation were present on the left ventricular endocardial surface, but no obvious coronary occlusion was found. Both children with the inferoposterior changes were examined at necropsy, and showed extensive thinning of most of the left ventricle, though the outflow and septal walls were less affected. All three infants showed the usual thickening of the endothelium, and all had involvement of the mitral valve structures.

\section{Discussion}

Although infarct patterns in infancy are rare, their appearance on the electrocardiogram is often of diagnostic value. They have been reported in children with myocarditis, cardiomyopathy; EFE, coronary calcinosis, and anomalous left coronary artery (Apley, 1961; Dominguez, Lendrum, and Pick, 1959; Noren et al., 1964; Thomas et al., 1956). The diagnosis of anomalous left coronary artery is usually the first to be entertained clinically when an infant under 1 year of age has evidence of significant myocardial damage on the electrocardiogram. Cardiac catheterization is usually done in infants presenting with heart failure, possibly caused by cardiomyopathy or myocarditis, specifically to rule out the possibility of an anomalous left coronary artery since this lesion is surgically correctable.

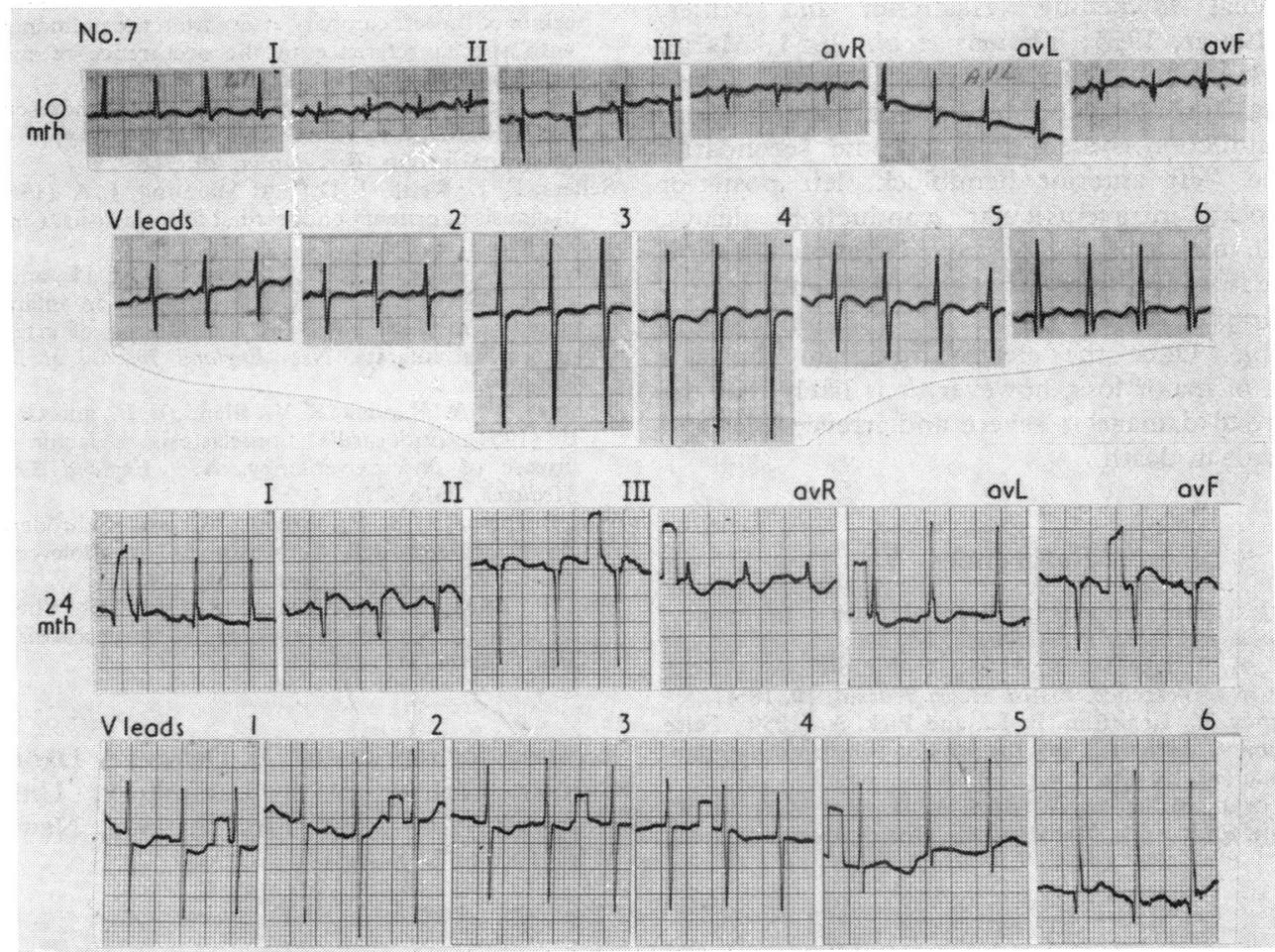

FIG. 2 The admitting electrocardiogram at 10 months of age and an electrocardiogram at 24 months, just before phenolization, are shown for Case 7. Note the $q$ waves in II, III, aVF, and V6 on the admitting electrocardiogram, with a delayed transition between V5-6. ST and $T$ wave changes are not too striking. By 24 months of age, there are $Q S$ complexes in II, III, and $a V F$ with a distinct left axis deviation. Transition occurs between V4-5 and ST changes are more pronounced. 
Although infarct patterns occur less often in EFE (Vlad, Rowe, and Keith, 1955), they have been reported in several cases. Of those reviewed, all but one of the children with myocardial damage on the electrocardiogram died (Hastreiter and Miller, 1964; Lintermans et al., 1966; Ruttenberg et al., 1964; Auld and Watson, 1957; Linde and Adams, 1963; Lambert and Vlad, 1958). In the one child who lived, the electrocardiogram was not reproduced in its entirety but showed ST elevation in the anterior praecordial leads with $\mathrm{q}$ waves in leads I and V6 (no q in aVL and no loss of anterior forces) (Linde and Adams, 1963). These cases plus the four children presented here suggest that the 'infarct' pattern when seen in children with EFE is a negative prognostic sign for survival. Some infants may die during the acute episode of failure without this finding on the electrocardiogram, but in those who survive the initial failure, there is a good correlation between the electrocardiogram and clinical course. At necropsy, there is often much fibrosis and thinning of the myocardium along with the typical endothelial thickening (Hastreiter and Miller, 1964; Letter, 1953; Thomas et al., 1954; Marini and Pinca, 1962). With this type of damage, loss of electrical force may occur ('infarct patterns') and the conduction system may become secondarily involved (left anterior hemiblock, left posterior hemiblock, intraventricular conduction delays, etc.). If muscle is not destroyed completely or if damage is minor, then survival is likely and electrocardiographic abnormalities may be limited and reversible. Once the electrocardiogram shows a pattern of major loss, however, it is likely that the myocardial damage is severe and irreversible, and will result in death.

\section{References}

Apley, J. (1961). Primary myocardial disease in infancy. Archives of Disease in Childhood, 36, 366.

Auld, W. H. R., and Watson, H. (1957). Fibro-elastosis of the heart in adolescence. British Heart fournal, 19, 186.

Dominguez, P., Lendrum, B. L., and Pick, A. (1959). False 'coronary patterns' in the infant electrocardiogram. Circulation, 19, 409.

Forfar, J. O., Miller, R. A., Bain, A. D., and Macleod, W. (1964). Endocardial fibroelastosis. British Medical fournal, 2, 7.
Hastreiter, A. R., and Miller, R. A. (1964). Management of primary endomyocardial disease. The myocarditisendocardial fibroelastosis syndrome. Pediatric Clinics of North America, 11, 401.

Lambert, E. C., and Vlad, P. (1958). Primary endomyocardial disease. Pediatric Clinics of North America, 5, 1057.

Letter, C. R. (1953). Endocardial fibroelastosis. Annals of Internal Medicine, 38, 573.

Linde, L. M., and Adams, F. H. (1963). Prognosis in endocardial fibroelastosis. American fournal of Diseases of Children, 105, 329.

Lintermans, J. P., Kaplan, E. L., Morgan, B. C., Baum, D., and Guntheroth, W. G. (1966). Infarction patterns in endocardial fibroelastosis. Circulation, 33, 202.

McCormick, W. F. (1958). Endocardial fibroelastosis. Southern Medical fournal, 51, 1232.

Manning, J. A., and Keith, J. D. (1964). Fibroelastosis in children. Progress in Cardiovascular Diseases, 7, 172.

Marini, A., and Pinca, A. (1962). Electrocardiographic anatomical correlations in endocardial fibroelastosis. Acta Cardiologica, 17, 1.

Moller, J. H., Lucas, R. V., Jr., Adams, P., Jr., Anderson, R. C., Jorgens, J., and Edwards, J. E. (1964). Endocardial fibroelastosis: a clinical and anatomic study of 47 patients with emphasis on its relationship to mitral insufficiency. Circulation, 30, 759.

Noren, G. R., Raghib, G., Moller, J. H., Amplatz, K., Adams, P., Jr., and Edwards, J. E. (1964). Anomalous origin of the left coronary artery from the pulmonary trunk with special reference to the occurrence of mitral insufficiency. Circulation, 30, 171.

Ruttenberg, H. D., Jue, K. L., Elliott, L. P., Anderson, R. C., and Edwards, J. E. (1964). Cardiac myopathy, probably of congenital origin. Circulation, 29, 768.

Sellers, F. J., Keith, J. D., and Manning, J. A. (1964). The diagnosis of primary endocardial fibroelastosis. Circulation, 29, 49.

Thomas, W. A., Lee, K. T., McGavran, M. H., and Rabin, E. R. (1956). Endocardial fibroelastosis in infants associated with thrombosis and calcification of arteries and myocardial infarcts. New England fournal of Medicine, 255, 464.

Thomas, W. A., Randall, R. V., Bland, E. F., and Castleman, B. (1954). Endocardial fibroelastosis: a factor in heart disease of obscure etiology. New England fournal of Medicine, 251, 327.

Van Buchem, F. S. P., Arends, A., and Schröder, E. A. (1959). Endocardial fibro-elastosis in adolescents and adults. British Heart fournal, 21, 229.

Vlad, P., Rowe, R. D., and Keith, J. D. (1955). The electrocardiogram in primary endocardial fibroelastosis. British Heart fournal, 17, 189.

Requests for reprints to Dr. Delores A. Danilowicz, Cardiac Catheterization Laboratory, University Hospital; H-617, 560 First Avenue, New York, N.Y. 10016, U.S.A. 